\title{
Effect of Th1/Th2 Cytokine Pretreatment on RSV-Induced Gene Expression in Airway Epithelial Cells
}

\author{
Yumi Yamada ${ }^{a}$ b Kenji Matsumoto ${ }^{a}$ Noriko Hashimoto ${ }^{a}$ Miwako Saikusa ${ }^{c}$ \\ Toshiki Homma $^{a}$ Shigemi Yoshiharab Hirohisa Saito ${ }^{a}$ \\ a Department of Allergy and Immunology, National Research Institute for Child Health and Development, Tokyo, \\ ${ }^{b}$ Department of Pediatrics, Dokkyo University School of Medicine, Tochigi, and ${ }^{\mathrm{C}}$ Yokohama Health Research \\ Institute, Yokohama, Japan
}

\section{Key Words}

Respiratory syncytial virus $\cdot$ Th1 $\cdot$ Th2 $\cdot$ Cytokine $\cdot$ CCL2

\begin{abstract}
Background: Respiratory syncytial virus (RSV) infection in infants with Th2 predisposition is thought to increase the risk of allergic sensitization, recurrent wheezing, and bronchial asthma during childhood. We attempted to clarify the molecular mechanisms by which Th1/Th2 predisposition in the host alters RSV infection and facilitates airway inflammation. Methods: A549 human airway epithelial cells were inoculated with live or UV-treated RSV after pretreatment with either a combination of tumor necrosis factor (TNF)- $\alpha$ and interferon- $\gamma$ (Th1-primed) or a combination of TNF- $\alpha$ and interleukin-4 (Th2-primed) for $48 \mathrm{~h}$. The gene and protein expression profiles of RSV-infected A549 cells were examined. Results: GeneChip analysis indicated that, at $96 \mathrm{~h}$ after inoculation with RSV, the expression of 62 genes was specifically enhanced (more than 2-fold by normalized data) in Th2-primed cells compared to that in unprimed or Th1-primed cells. An increase in mRNA and protein levels of monocyte chemoattractant protein (MCP)-1/CCL2 among those 62 genes was confirmed by real-time PCR and cytometric bead assay, re-
\end{abstract}

spectively. RSV replication was markedly diminished in Th1primed airway epithelial cells but not in Th2-primed cells, which was presumably caused at least in part by the early induction of antiviral genes. Conclusions: These results suggest that Th1/Th2 predisposition in the host prior to RSV infection critically regulates inflammatory reactions in the airways through alteration of gene expression, and that MCP-1/ CCL2 plays an important role in the pathogenesis of severe RSV infection and the subsequent development of asthma in Th2-predisposed hosts.

Copyright $\odot 2010$ S. Karger AG, Basel

\section{Introduction}

Acute bronchiolitis is a distressing, potentially lifethreatening respiratory condition in infancy. The majority of cases are caused by respiratory syncytial virus (RSV), and all affected infants experience an intense inflammatory response in the airways. Both retrospective and prospective studies have well documented that infants with RSV bronchiolitis who develop symptoms severe enough to warrant hospitalization often develop recurrent wheezing, allergic sensitization, and bronchial

\section{KARGER}

Fax +41613061234 E-Mail karger@karger.ch www.karger.com
(C) 2010 S. Karger AG, Basel

$1018-2438 / 11 / 1543-0185 \$ 38.00 / 0$

Accessible online at:

www.karger.com/iaa
Correspondence to: Dr. Yumi Yamada

Department of Allergy and Immunology

National Research Institute for Child Health and Development

2-10-1, Okura, Setagaya-ku, Tokyo 157-8535 (Japan)

Tel. +81 33416 0181, Fax +81 35494 7028, E-Mail yu-yama@ dokkyomed.ac.jp 
asthma during childhood $[1,2]$. Sigurs et al. followed up a cohort of 47 children who had been admitted to the hospital with severe RSV bronchiolitis in infancy until the age of 13 years and noted that RSV bronchiolitis severe enough to cause hospitalization is a risk factor for allergic asthma in early adolescence [1]. Although the relationship between RSV bronchiolitis and asthma has been widely reported, it remains unclear whether RSV bronchiolitis contributes to asthma inception or simply identifies infants who are at an increased risk for subsequent wheezing [3-5].

Several investigators have shown the possibility that RSV per se directly induces Th2-type immune responses [6-8] and airway hyperresponsiveness $[9,10]$. However, although $70-80 \%$ of previously healthy infants are infected with RSV in the first year of life, only a small proportion of these infants develops severe bronchiolitis and asthma. Recent interest has been focused on the associations of the host immune responses with disease severity [11]. Children exposed to RSV in early life or at a specific age tend to have a higher risk of severe lower respiratory infection [12], and this association was explained at least in part by the immature or impaired Th1 immune response in infancy $[13,14]$. In prospective studies, reduced interferon (IFN)- $\gamma$ secretion from mitogen-stimulated cord blood cells has been linked to an increased number of moderate-to-severe viral respiratory infections [15]. Moreover, allergic sensitization increased mucous hypersecretion and airway hypersensitivity in a murine model of RSV infection $[16,17]$. Indeed, polymorphisms of interleukin (IL)-13, IL-4, and IL-4R have been reported to be associated with the onset of bronchiolitis [18, 19]. These findings indicate that variation in host immune responses is relevant to the development of bronchiolitis and subsequent asthma.

RSV-inducing genes in unprimed epithelial cells have been well documented using a differential display method or microarrays [20-22]. Although a few investigators reported that RSV and Th1/Th2 cytokines enhanced the expression of thymus- and activation-regulated chemokine [23] and costimulatory molecules [24], the effect of Th1/Th2 cytokine pretreatment on RSV-induced gene expression profiles in human airway epithelial cells has not yet been systematically studied. In the present study, to clarify the mechanism by which Th1/Th2 predisposition in the host alters RSV infection and facilitates airway inflammation, we evaluated gene expression profiles using the GeneChip system in RSVinfected human airway epithelial cells pretreated with Th1/Th2 cytokine.

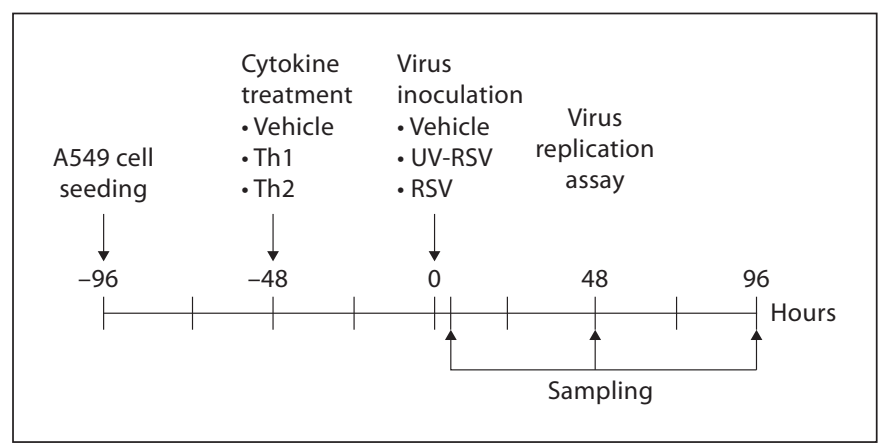

Fig. 1. Experimental design.

\section{Materials and Methods}

\section{Reagents}

Recombinant human tumor necrosis factor (TNF)- $\alpha$ and IL-4 were purchased from R\&D Systems (Minneapolis, Minn., USA). Recombinant human IFN- $\gamma$ was purchased from Genzyme (Cambridge, Mass., USA).

\section{RSV Preparation}

RSV strain Long (prototype RSV group A strain) grown in HEp-2 cells was provided by Dr. Hiroyuki Tsutsumi, Sapporo University, Hokkaido, Japan [25]. The stock virus titer was $10^{7}$ $\mathrm{PFU} / \mathrm{ml}$ by standard plaque assay. Virus pools were aliquoted, quick-frozen, and stored at $-70^{\circ} \mathrm{C}$ until used. RSV inactivated by ultraviolet (UV) light irradiation [25] was UV-RSV, and nonirradiated RSV was live RSV. Thus, complete virus inactivation was confirmed by plaque formation assay.

\section{Cell Culture}

The human pulmonary epithelial type II cell line A549 was obtained from the American Type Culture Collection (Rockville, Md., USA) and cultured in Dulbecco's modified Eagle's medium (DMEM)/F12 (Invitrogen, Carlsbad, Calif., USA) supplemented with $5 \%$ fetal calf serum (HyClone, Logan, Utah, USA). These cells provide a useful model for the study of RSV infection [22, 26]. For the experiments, cells were detached from the plastic by incubation in 5\% trypsin and EDTA for $5 \mathrm{~min}$, washed, and then seeded into 6 -well microplates at a density of $5 \times 10^{4}$ cells/well 4 days before RSV infection. The cells were generally $80 \%$ confluent by the second passage after seeding.

\section{Experimental Design}

The experimental design is outlined in figure 1 . To mimic the immune predisposition of the host, A549 cells were pretreated for $48 \mathrm{~h}$ with $0.1 \%$ bovine serum albumin (BSA)-phosphate-buffered saline (PBS) (vehicle or unprimed), $10 \mathrm{ng} / \mathrm{ml}$ TNF- $\alpha$ alone, a combination of $10 \mathrm{ng} / \mathrm{ml} \mathrm{TNF}-\alpha$ and $10 \mathrm{ng} / \mathrm{ml} \mathrm{IFN-} \gamma$ (Th1-primed), or a combination of $10 \mathrm{ng} / \mathrm{ml} \mathrm{TNF-} \alpha$ and $10 \mathrm{ng} / \mathrm{ml} \mathrm{IL-4} \mathrm{(Th2-}$ primed) before inoculation with RSV. These optimal concentrations were determined in our preliminary experiments and by referring to previous reports [27]. 
Table 1. Primers for real-time RT-PCR

\begin{tabular}{|c|c|c|c|c|}
\hline Target gene & $\begin{array}{l}\text { Accession } \\
\text { No. }\end{array}$ & Forward sequence $\left(5^{\prime}-3^{\prime}\right)$ & Reverse sequence $\left(5^{\prime}-3^{\prime}\right)$ & $\begin{array}{l}\text { Amplicon } \\
\text { size, bp }\end{array}$ \\
\hline CCL5 & NM002985 & CAGTCGTCTTTGTCACCCGAA & TCCCAAGCTAGGACAAGAGCA & 165 \\
\hline CCL20 & NM004591 & GGCCAATGAAGGCTGTGACAT & TGGATTTGCGCACACAGACA & 73 \\
\hline ICAM-1 & NM000201 & GGTAGCAGCCGCAGTCATAATG & TGGCGGTTATAGAGGTACGTGC & 60 \\
\hline MMP-1 & NM002421 & ACATGCGCACAAATCCCTTCT & CGTAAGCAGCTTCAAGCCCAT & 93 \\
\hline MMP-10 & NM002425 & TGCCAGGATGGTGACACACA & CССССТАTCTCGCCTAGCAA & 65 \\
\hline IL-8 & NM000584 & GTCTGCTAGCCAGGATCCACAA & GAGAAACCAAGGCACAGTGGAA & 51 \\
\hline SOCS-3 & NM003955 & GGATTCTACTCTGTGCCTCCTGACT & GAGTATGTGGCTTTCCTATGCTGG & 101 \\
\hline CCL2 & NM002982 & TCAGCCAGATGCAATCAATGC & GGACACTTGCTGCTGGTGATTC & 111 \\
\hline IFIT1 & NM001548 & GCCATTTTCTTTGCTTCСССТА & TGCCCTTTTGTAGCCTCCTTG & 330 \\
\hline MX1 & NM002462 & AGCTGCCAGGCTTTGTGAATTA & GGACTGGAAAGCCCCAAAATC & 368 \\
\hline GAPDH & NM002046 & GAAGGTGAAGGTCGGAGTC & GAAGATGGTGATGGGATTTC & 226 \\
\hline
\end{tabular}

After this cytokine priming, A549 cells were inoculated with live or UV-RSV at a multiplicity of infection of 2 , and adsorbed for $1 \mathrm{~h}$ at $37^{\circ} \mathrm{C}$ under $5 \% \mathrm{CO}_{2}$. After removal of the viral solution by washing, $2 \mathrm{ml}$ of DMEM was added to the plates. The cells were cultured for up to $96 \mathrm{~h}$ at $37^{\circ} \mathrm{C}$. Cells and supernatants were harvested at various time points and stored at $-70^{\circ} \mathrm{C}$ until needed for analysis. The supernatants were used for cytometric bead array and virus replication assay.

\section{GeneChip Expression Analysis}

Total RNA samples were isolated from A549 cells using an RNeasy kit (Qiagen, Hilden, Germany), and digested with RNasefree DNase I (Qiagen) following the manufacturer's instructions. Five micrograms of total RNA from cells harvested at $96 \mathrm{~h}$ was used to prepare cRNA. Gene expression was examined using a GeneChip Human Genome U133 Plus 2.0 probe array (Affymetrix, Santa Clara, Calif., USA), which contains the oligonucleotide probe set for 54,120 full-length genes/expressed sequence tags, according to the manufacturer's protocol [28]. Data analysis was performed with GeneSpring software version 7.3.1 (Silicon Genetics, Redwood City, Calif., USA). To normalize the staining intensity variations among chips, the average difference values for all genes on a given chip were divided by the median value for the expression of all genes on the chip. To eliminate genes containing only background noise, genes were selected only if the raw data were $>200$ and the gene expression was judged to be 'present' by GeneChip Analysis Suite 5.0 (Affymetrix). Hierarchical clustering analysis was performed using a minimum distance value of 0.001 , a separation ratio of 0.5 , and the standard definition of the correlation distance.

\section{Quantitative Real-Time RT-PCR}

Total RNA samples were reverse transcribed to cDNA using SuperScript III reverse transcriptase (Invitrogen). The primers were designed based on sequences from GenBank and are shown in table 1 . Real-time quantitative RT-PCR analyses were performed with the ABI Prism 7700 Sequence Detection System (Applied Biosystems, Foster City, Calif., USA) using SYBR Green I PCR reagents (Applied Biosystems) as previously reported [28].
The copy number is expressed as the number of transcripts per nanogram of total RNA. To determine the exact copy numbers of the target genes, quantified concentrations of the purified PCR product of CCL2, CCL5, CCL20, ICAM-1, MMP-1, MMP-10, SOCS-3, and IL-8 were serially diluted and used as standards in each experiment. Aliquots of cDNA equivalent to $5 \mathrm{ng}$ of the total RNA samples were used for each real-time PCR. The mRNA expression levels were normalized with glyceraldehyde 3-phosphate dehydrogenase (GAPDH) levels in each sample [28].

\section{Assay of Chemokines by Cytometric Bead Array}

The concentrations of monocyte chemoattractant protein-1 (MCP-1)/CCL2 in the supernatant at $96 \mathrm{~h}$ of incubation was measured with a cytometric bead array (CBA) kit (BD Biosciences Pharmingen, San Diego, Calif., USA) using a 4-color FACSCalibur flow cytometer (Becton Dickinson, San Diego, Calif., USA). In the CBA, 3 beads of regulated on activation, normal T cells expressed and secreted (RANTES)/CCL5, IL-8, and CCL2 populations with distinct fluorescence intensities had been coated with capturing antibodies specific for these different chemokines. These bead populations could be resolved in the fluorescence channels of the flow cytometer. After the beads had been incubated with $12.5 \mu$ l of culture supernatant, different chemokines in the supernatant were captured by their corresponding beads. The chemokine-capturing beads were then mixed with phycoerythrin-conjugated detection antibodies to form sandwich complexes. Following incubation, washing, and the acquisition of fluorescence data, the results were generated in a graphic format using BD CBA software. Standard curves were generated for each chemokine using the mixed chemokine standard provided in the kit. The concentration for each chemokine in the culture supernatants was determined by interpolation from the corresponding standard curve. The minimal detection limit of the assay for each cytokine was as follows: $0.2 \mathrm{pg} / \mathrm{ml} \mathrm{IL-8,2.7} \mathrm{pg/ml} \mathrm{CCL2,} \mathrm{and} 1.0$ $\mathrm{pg} / \mathrm{ml}$ CCL5.

\section{RSV Replication Assay}

The cell suspension and supernatant fluids stored at $48 \mathrm{~h}$ after inoculation were subjected to the measuring of the RSV yield, as 
previously described [29]. Briefly, the sample and medium were added to the plates containing HEp-2 cells, and then incubated at $34^{\circ} \mathrm{C}$ for 7 days. Syncytium formation in the wells was visually inspected, and viral yields were expressed as log 50\% tissue culture infective dose units/ml using the Karber method [30].

\section{Results}

\section{Gene Expression Profiles in RSV-Infected Cells}

Pretreated with Th1/Th2 Cytokines

To identify genes enhanced in RSV-infected airway epithelial cells pretreated with Th1/Th2 cytokines, the gene expression profiles were explored using the GeneChip system at $96 \mathrm{~h}$ after inoculation. We first divided the genes into the following 2 probe sets: the first probe set was increased more than 2 -fold in unprimed RSV-infected cells when compared to the vehicle control, UV-RSV, and Th1- or TNF- $\alpha$-primed RSV-infected cells (I in fig. 2); the second probe set was increased more than 2-fold in Th2-primed RSV-infected cells when compared to the vehicle control, UV-RSV, and Th1- or TNF- $\alpha$ -

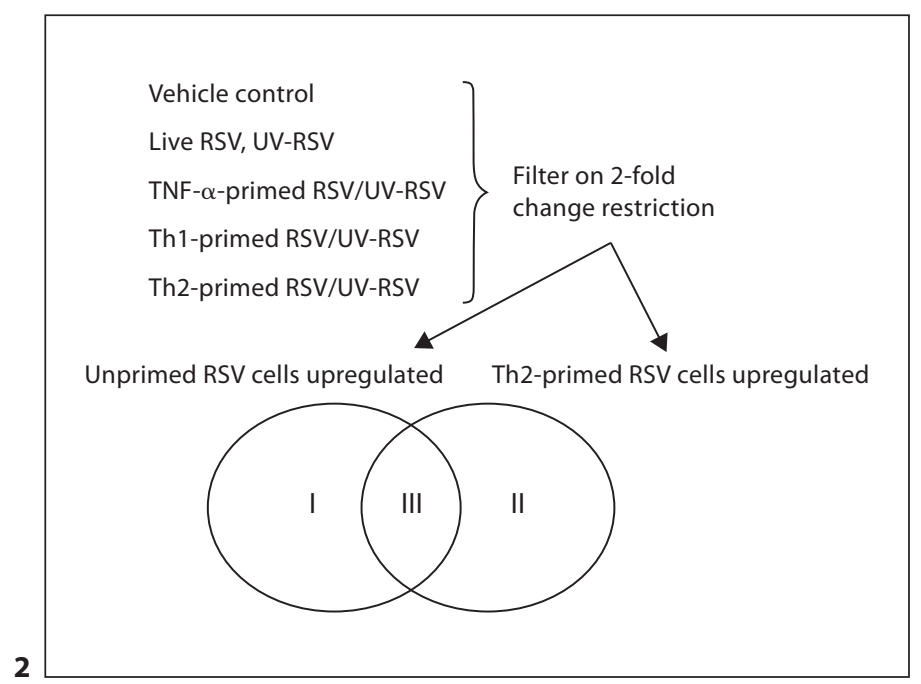

Fig. 2. Relationships between probe sets upregulated in unprimed RSV-infected cells or Th2-primed RSV-infected cells by more than 2-fold compared to those in the vehicle control, UV-RSV, and Th1- or TNF- $\alpha$-primed RSV-infected cells. The Venn diagram shows the intersections between 2 probe sets upregulated in unprimed RSV-infected cells (I) and Th2-primed RSV-infected cells (II) at $96 \mathrm{~h}$ after inoculation. A total of 348 genes was common to both probe sets (III).

Fig. 3. The expression of 62 probe sets was specifically increased in Th2-primed RSV-infected cells (fig. 2). Hierarchical clustering primed RSV-infected cells (II in fig. 2). Within these probes, the expression of 348 probe sets commonly increased more than 2 -fold (III in fig. 2). These 348 probe sets included chemokines (RANTES/CCL5, LARC/ CCL20), cytokines (IL-8), an adhesion molecule (intercellular adhesion molecule ICAM-1), tissue remodeling genes (matrix metalloproteinases MMP-1 and MMP-10), and suppressor of cytokine signaling (SOCS)-3.

On the other hand, the expression of 62 probe sets specifically increased in Th2-primed RSV-infected cells. By clustering analysis of these 62 probe sets, we found that the expression level of CCL2 (GenBank accession No. S69738) was the most markedly increased (fig. 3).

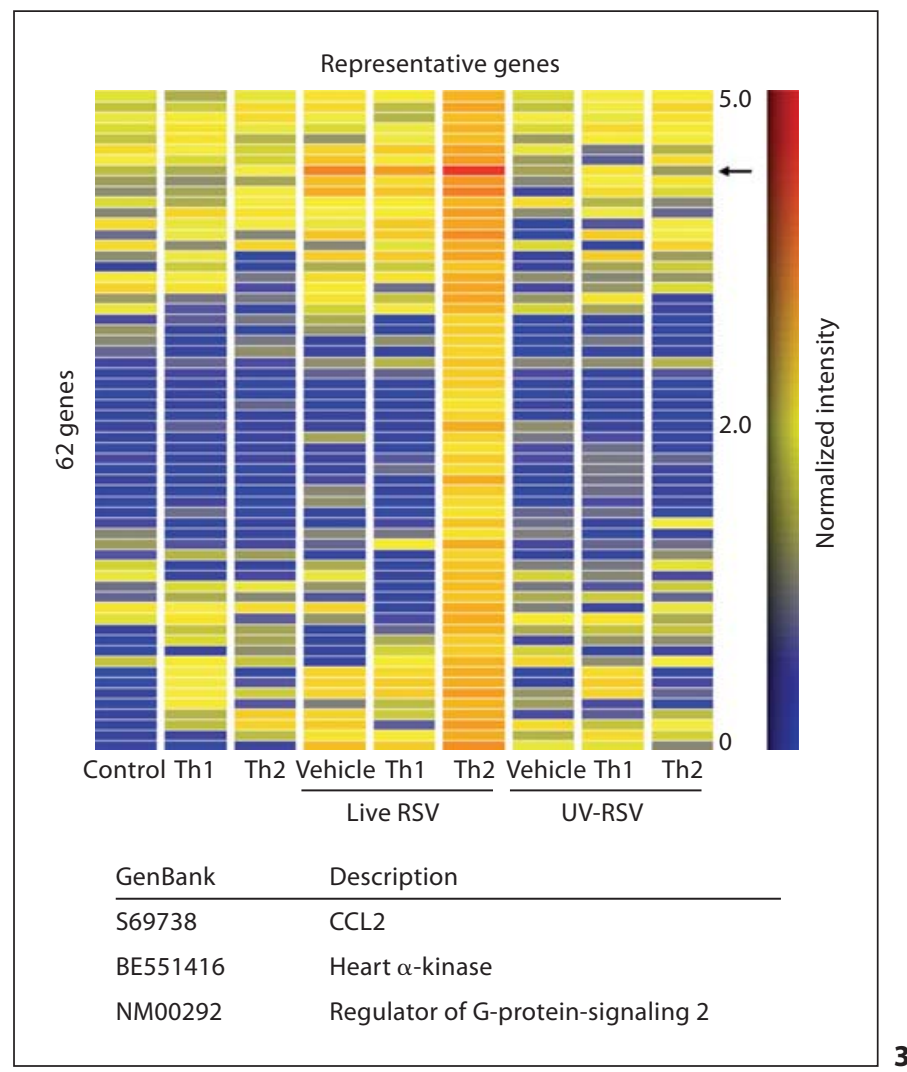

analysis shows the expression level of these 62 probe sets. The arrow indicates the gene expression level of CCL2. The upregulated genes are indicated by shades of red and the downregulated genes are indicated by shades of blue in clustering analysis.

Fig. 4. Expression levels of the mRNAs of representative molecules (CCL2, CCL5, CCL20, ICAM-1, MMP-1, MMP-10, SOCS-3, and IL-8) in A549 cells at 6, 48, and $96 \mathrm{~h}$ after inoculation as determined by real-time PCR. The results are expressed as the mean \pm SEM of duplicates from a single experiment. 


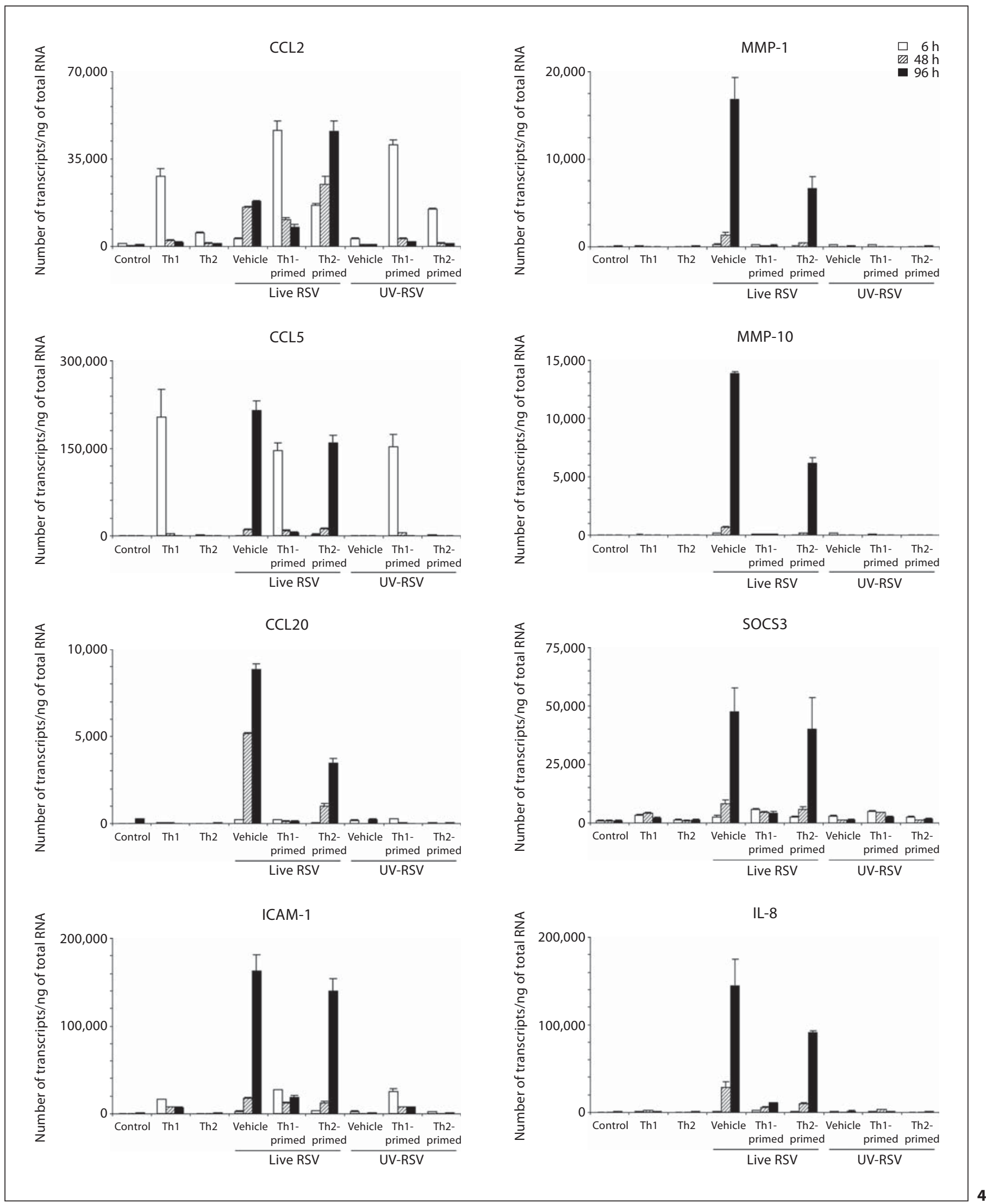




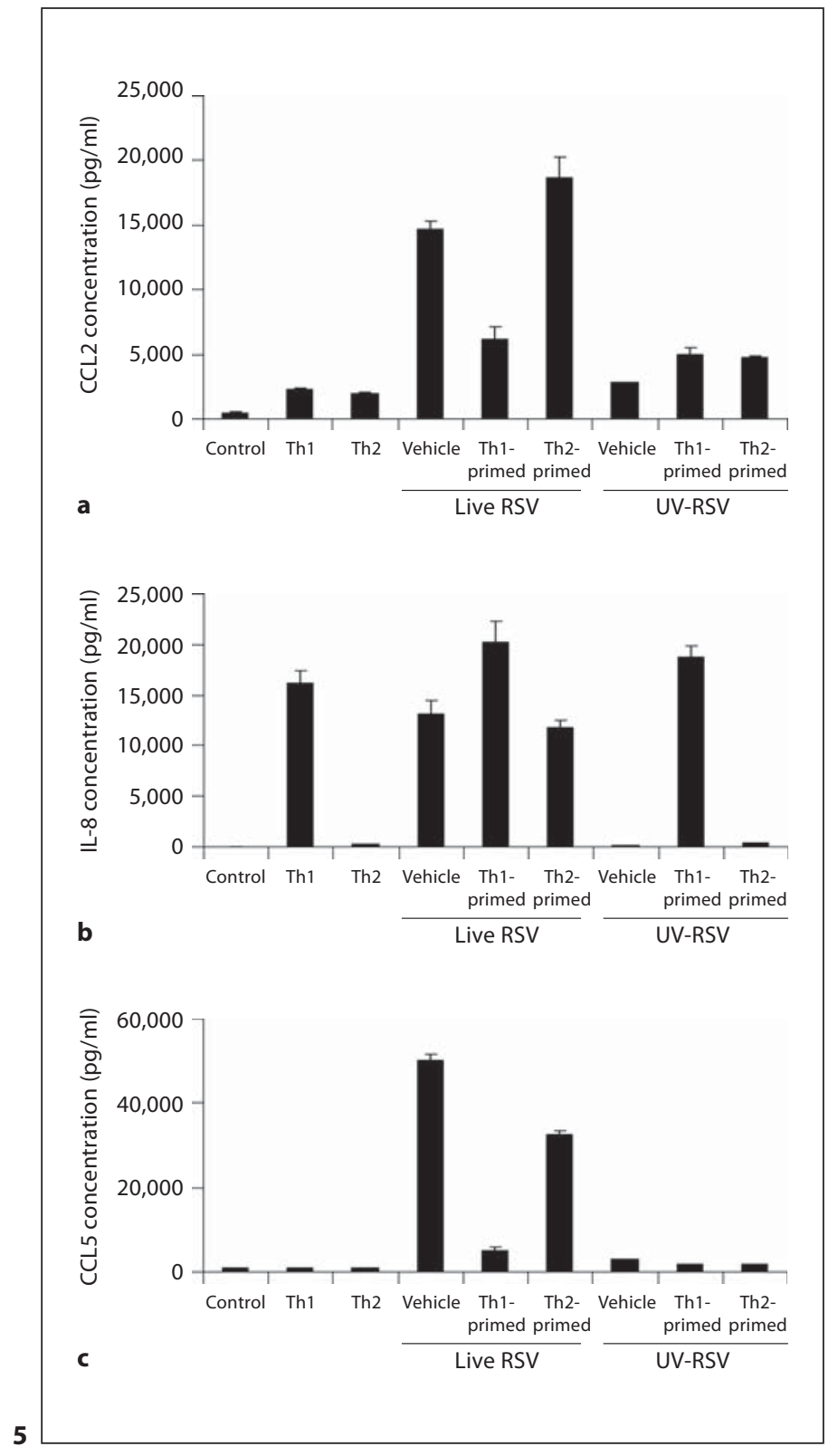

Fig. 5. CCL2 (a), IL-8 (b), and CCL5 (c) concentration in the culture supernatant as determined by CBA at $96 \mathrm{~h}$ after inoculation. The results are expressed as the mean \pm SEM from 2 separate experiments.

Fig. 6. a RSV replication assay in unprimed, TNF- $\alpha$-primed, Th1primed, and Th2-primed cells at $48 \mathrm{~h}$ after inoculation with live

Time Course of Expression of $m R N A$ of Representative Molecules by Real-Time PCR

To confirm the result of the microarray analysis, we next examined the actual expression levels of the mRNAs of the representative molecules: CCL2, CCL5, CCL20, ICAM-1, MMP-1, MMP-10, SOCS-3, and IL-8 in A549

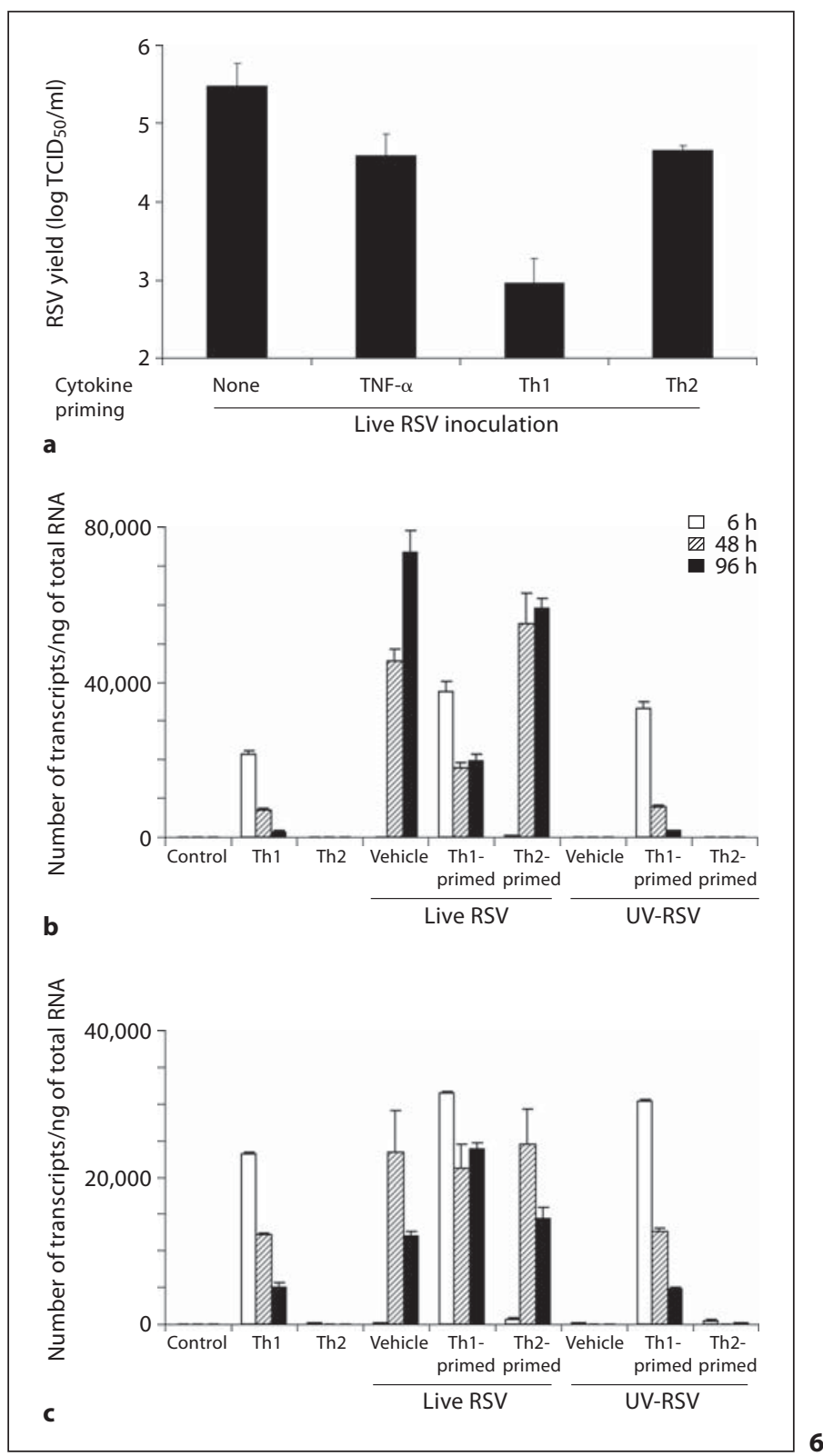

RSV. The results are shown as the mean \pm SEM from 3 separate experiments. TCID $_{50}=50 \%$ tissue culture infective dose. Expression levels of mRNAs of antiviral genes IFIT1 (b) and MX1 (c) in A549 cells at 6,48 , and $96 \mathrm{~h}$ after inoculation as determined by real-time PCR. The results are expressed as the mean \pm SEM of duplicates from a single experiment.

cells at different time points $(6,48$, and $96 \mathrm{~h})$ by real-time PCR (fig. 4). Expression of CCL2 and CCL5 mRNAs was induced in all Th1-primed cells at $6 \mathrm{~h}$, but not at 48 and $96 \mathrm{~h}$. Notable expression of CCL20, ICAM1, MMP-1, MMP10, SOCS-3, and IL-8 mRNAs was induced only in unprimed RSV-infected and Th2-primed RSV-infected 
cells at $96 \mathrm{~h}$, but not in all Th1-primed cells; the expression levels were higher in unprimed RSV-infected cells than in Th2-primed RSV-infected cells. In contrast, the expression level of CCL2 mRNA in Th2-primed RSV-infected cells at $96 \mathrm{~h}$ was 6 -fold higher than that in Th1primed cells, and 2.5-fold higher than that in unprimed RSV-infected cells. TNF- $\alpha$ alone or TNF- $\alpha$-primed RSVinfected cells expressed mRNA levels similar to the control and unprimed RSV-infected cells, respectively (data not shown).

\section{Chemokine Concentrations in the Supernatant}

We further confirmed CCL2 concentrations in the supernatant by CBA at $96 \mathrm{~h}$ after inoculation (fig. 5). Similar to mRNA expression, the levels of CCL2 and IL-8 proteins were remarkably high in unprimed RSV-infected and Th2-primed RSV-infected cells, and low in Th1primed cells (fig. 5a, b). Moreover, the CCL2 protein level in Th2-primed RSV-infected cells was slightly (1.2fold) higher than that in unprimed RSV-infected cells, but was 3-fold higher than that in Th1-primed cells (fig. 5a). The expression of the CCL5 protein was induced in all Th1-primed cells and live RSV-infected cells (fig. 5c).

Viral Replication Assay and mRNA Expression Levels of Antiviral Proteins by Real-Time PCR

To examine whether Th1/Th2 cytokine affects viral replication in an in vitro culture, viral replication assay was performed using supernatant at $48 \mathrm{~h}$ after the inoculation of live RSV. The viral yield was notably suppressed in Th1-primed cells but not in Th2-primed cells (fig. 6a). To clarify the mechanisms by which Th1-priming suppressed viral replication, the mRNA expression of 2 antiviral proteins [interferon-induced protein with tetratricopeptide repeats 1 (IFIT1) and myxovirus resistance 1 (MX1)] was measured at different time points $(6,48$, and $96 \mathrm{~h}$ ) by real-time PCR. In all Th1-primed cells, mRNA expression for these 2 molecules was notably induced at $6 \mathrm{~h}$ (fig. 6b, c). On the other hand, in unprimed RSV-infected cells and Th2-primed RSV-infected cells, these mRNA levels increased at $48 \mathrm{~h}$, whereas the levels decreased in Th1-primed cells (fig. 6b, c).

\section{Discussion}

Several lines of evidence suggest that the immune predisposition of the host prior to RSV infection plays an important role in the progression of bronchiolitis as well as on the subsequent development of asthma. In the pres- ent study, we examined the effect of Th1/Th2 cytokine priming on the RSV-inducible gene expression profiles in airway epithelial cells in order to clarify the molecular mechanisms by which RSV infection causes bronchiolitis or subsequent asthma in some individuals, particularly in Th2-predisposed hosts.

In the first series of experiments, we analyzed the gene expression profiles at $96 \mathrm{~h}$ to clarify the effect of Th1/Th2 cytokine priming on the RSV-inducible gene. It is well known that viral antigen production and syncytium formation in cell lines appear 48-96 h after live RSV inoculation [31]. Several studies using A549 cells infected with live RSV have identified an induction of molecular expression at $48 \mathrm{~h}[32,33]$. Therefore, first, the gene expression profiles were explored at $96 \mathrm{~h}$ after inoculation in this study. By hierarchical clustering analysis, we extracted the expression profiles of 348 genes including CCL5, CCL20, IL-8, ICAM-1, MMP-1, MMP-10, and SOCS-3 whose expression levels increased more than 2 -fold by live RSV and Th2 priming but not by Th1 priming in A549 cells at $96 \mathrm{~h}$ after inoculation. Recent studies have revealed that RSV infection in airway epithelial cells induces the expression and secretion of various cytokines, chemokines, arachidonic acid metabolites, reactive oxygen species, cell surface molecules, and transcription factors by oligonucleotide arrays $[20,22]$. In the present study, we found that Th1/Th2 predisposition in the host prior to RSV infection critically regulates inflammatory reactions in the airways through an alteration of the induction of these genes. However, the expression levels of these mRNA and proteins were higher in unprimed RSVinfected cells than in Th2-primed RSV-infected cells (fig. 4). Therefore, these genes were considered not to be specific Th2 priming-responsible genes. CCL5 mRNA and protein expression was induced in all Th1-primed cells and live RSV-infected cells (fig. 4, 5c). This finding suggests that CCL5 was predominantly induced by lowdose Th1 cytokine in A549 cells. CCL5 has been known to be associated with the severity of RSV bronchiolitis [34] and the risk of recurrent wheezing [35]. In support of this hypothesis, the exposure of epithelial cells to IFN- $\gamma$ in combination with RSV infection induced a significant increase in RANTES production, which was synergistic with respect to that obtained by RSV infection or IFN- $\gamma$ treatment alone [33].

Specifically, the expression of 62 probe sets was increased in Th2-primed RSV-infected cells but not in unprimed or Th1-primed RSV-infected cells (fig. 2). Clustering analysis of these 62 probe sets revealed that CCL2 was the most significantly induced gene (fig. 3). 
When we further analyzed the kinetics of CCL2 mRNA expression by real-time PCR, CCL2 mRNA in Th2primed RSV-infected cells was induced at $48 \mathrm{~h}$ after RSV inoculation and peaked at $96 \mathrm{~h}$ (fig. 4). We also confirmed the protein levels of CCL2 in the supernatant of the cells at $96 \mathrm{~h}$ after inoculation (fig. 5a). The expression of MCP1 in RSV-infected A549 cells has been previously described by several studies $[22,32]$. Chemokine CCL2 attracts CCR2- and CCR11-expressing cells such as neutrophils, basophils, monocytes, NK cells, and activated T cells, but not eosinophils [36, 37]. The progressive increase in CCL2 gene expression is consistent even with previous reports in nasopharyngeal secretions of infants and adults with severe RSV $[38,39]$. Therefore, CCL2 may play an important role in the development of more severe forms of RSV bronchiolitis by attracting neutrophils to the lung. CCL2 is also known as an important chemokine in the development of bronchial asthma, because CCL2knockout mice did not develop Th2-type immune responses [40], and CCL2 levels in bronchoalveolar lavage fluid in allergic asthma subjects were significantly higher than in the control subjects [41, 42]. It was long assumed that CCR6 was the predominant chemoattractant of immature dendritic cells to the airways [43]. However, CCR2, the receptor for CCL2, but not CCR6 has recently been found to be the predominant receptor for attracting Th2-cell-inducing dendritic cells to the lungs of asthma model mice [44]. Moreover, Culley et al. [45] suggested that CCL2 expression was increased and prolonged during Th2 cytokine-mediated immunopathology in BALB/c mice with RSV infection. Our study presents new information on highly inducible CCL2 expression in Th2primed RSV-infected A549 cells. It is suggested that our results can be reproduced in a mouse model with RSV infection. Thus, a blockade of CCL2 may elucidate the mechanism of immunopathology in RSV disease and lead to novel interventional therapeutics for reducing both the severity of RSV infection and the risk of subsequently developing asthma, especially in Th2-predisposed hosts. Further studies are needed to evaluate the association between CCL2 production and infants with RSV bronchiolitis and asthma.

Because it is well known that Th1 cytokines induce antiviral proteins in epithelial cells, we further examined the expression of antiviral proteins, including IFIT1 and $\mathrm{Mxl}$, in terms of time kinetics. Interestingly, these antiviral proteins were induced in unprimed RSV-infected cells and Th2-primed RSV-infected cells at later time points, but induced at early time points in all Th1-primed cells (fig. 6b, c). In addition, the viral yield was markedly diminished in Th1-primed cells but not in Th2-primed cells by RSV replication assay at $48 \mathrm{~h}$ after inoculation (fig. 6a). There is convincing evidence that the induction of antiviral proteins, including IFIT1 and Mx1, prior to RSV infection may suppress virus replication early on [46-48]. RSV replication is prolonged by a concomitant allergic response in cotton rats [49]. Therefore, in contrast to the Th1-predisposed hosts, it is possible to assume that the Th2-predisposed hosts prior to RSV infection could result in delayed RSV clearance, persistently leading to an increased inflammatory response by promoting viral replication and resulting in more severe illness.

In summary, we have demonstrated for the first time the gene expression profiles and viral replication in RSVinfected human airway epithelial cells pretreated with Th1/Th2 cytokines. The priming of airway epithelial cells with Th2 cytokine increased CCL2 expression specific to live RSV inoculation, and the viral yield was markedly diminished in Th1 cytokine-primed cells. The intrinsic host immunologic factors prior to RSV infection may be important in understanding its influence on the severity of RSV infection and the subsequent development of asthma.

\section{Acknowledgments}

This work was supported in part by grants from the National Institute of Biomedical Innovation (ID05-24 and ID05-41). We thank Prof. Hiroyuki Tsutsumi for providing live RSV and technical suggestions, and Ms. Kanami Orihara and Mr. Shuhei Fukuda for their skillful technical assistance.

References 
6 Legg JP, Hussain IR, Warner JA, Johnston SL, Warner JO: Type 1 and type 2 cytokine imbalance in acute respiratory syncytial virus bronchiolitis. Am J Respir Crit Care Med 2003;168:633-639.

7 Bont L, Heijnen CJ, Kavelaars A, van Aalderen WM, Brus F, Draaisma JT, Geelen SM, van Vught HJ, Kimpen JL: Peripheral blood cytokine responses and disease severity in respiratory syncytial virus bronchiolitis. Eur Respir J 1999;14:144-149.

8 Roman M, Calhoun WJ, Hinton KL, Avendano LF, Simon V, Escobar AM, Gaggero A, Diaz PV: Respiratory syncytial virus infection in infants is associated with predominant Th-2-like response. Am J Respir Crit Care Med 1997;156:190-195.

-9 Peebles RS Jr, Sheller JR, Collins RD, Jarzecka AK, Mitchell DB, Parker RA, Graham BS: Respiratory syncytial virus infection does not increase allergen-induced type 2 cytokine production, yet increases airway hyperresponsiveness in mice. J Med Virol 2001;63: 178-188.

-10 Schwarze J, Hamelmann E, Bradley KL, Takeda K, Gelfand EW: Respiratory syncytial virus infection results in airway hyperresponsiveness and enhanced airway sensitization to allergen. J Clin Invest 1997;100: 226-233.

- 11 Gern JE, Brooks GD, Meyer P, Chang A, Shen K, Evans MD, Tisler C, Dasilva D, Roberg KA, Mikus LD, Rosenthal LA, Kirk CJ, Shult PA, Bhattacharya A, Li Z, Gangnon R, Lemanske RF Jr: Bidirectional interactions between viral respiratory illnesses and cytokine responses in the first year of life. J Allergy Clin Immunol 2006;117:72-78.

-12 Wu P, Dupont WD, Griffin MR, Carroll KN, Mitchel EF, Gebretsadik T, Hartert TV: Evidence of a causal role of winter virus infection during infancy in early childhood asthma. Am J Respir Crit Care Med 2008;178: 1123-1129.

13 Holt PG, Sly PD: Interactions between RSV infection, asthma, and atopy: unraveling the complexities. J Exp Med 2002;196:12711275.

14 Ichinohe S, Hussain IR, Johnston SL: Cytokine production of RSV/PHA-stimulated tonsillar mononuclear cells: influences of age and atopy. Eur Respir J 2003;22:317-322.

-15 Copenhaver CC, Gern JE, Li Z, Shult PA, Rosenthal LA, Mikus LD, Kirk CJ, Roberg KA, Anderson EL, Tisler CJ, DaSilva DF, Hiemke HJ, Gentile K, Gangnon RE, Lemanske RF Jr: Cytokine response patterns, exposure to viruses, and respiratory infections in the first year of life. Am J Respir Crit Care Med 2004;170:175-180.

-16 Matsuse H, Behera AK, Kumar M, Rabb H, Lockey RF, Mohapatra SS: Recurrent respiratory syncytial virus infections in allergensensitized mice lead to persistent airway inflammation and hyperresponsiveness. J Immunol 2000;164:6583-6592.
17 Hashimoto K, Graham BS, Ho SB, Adler KB, Collins RD, Olson SJ, Zhou W, Suzutani T, Jones PW, Goleniewska K, O’Neal JF, Peebles RS Jr: Respiratory syncytial virus in allergic lung inflammation increases Muc5ac and gob-5. Am J Respir Crit Care Med 2004; 170: 306-312.

18 Puthothu B, Krueger M, Forster J, Heinzmann A: Association between severe respi ratory syncytial virus infection and IL13/IL4 haplotypes. J Infect Dis 2006;193:438-441.

19 Hoebee B, Rietveld E, Bont L, Oosten M, Hodemaekers HM, Nagelkerke NJ, Neijens HJ, Kimpen JL, Kimman TG: Association of severe respiratory syncytial virus bronchiolitis with interleukin-4 and interleukin-4 receptor alpha polymorphisms. J Infect Dis 2003;187:2-11

20 Domachowske JB, Bonville CA, Rosenberg HF: Gene expression in epithelial cells in response to pneumovirus infection. Respir Res 2001;2:225-233.

21 Tian B, Zhang Y, Luxon BA, Garofalo RP, Casola A, Sinha M, Brasier AR: Identification of NF-kappaB-dependent gene networks in respiratory syncytial virus-infected cells. J Virol 2002;76:6800-6814.

-22 Zhang Y, Luxon BA, Casola A, Garofalo RP, Jamaluddin M, Brasier AR: Expression of respiratory syncytial virus-induced chemokine gene networks in lower airway epithelial cells revealed by cDNA microarrays. J Virol 2001;75:9044-9058.

23 Monick MM, Powers LS, Hassan I, Groskreutz D, Yarovinsky TO, Barrett CW, Castilow EM, Tifrea D, Varga SM, Hunninghake GW: Respiratory syncytial virus synergizes with Th2 cytokines to induce optimal levels of TARC/CCL17. J Immunol 2007;179: 1648-1658.

24 Stanciu LA, Bellettato CM, Laza-Stanca V, Coyle AJ, Papi A, Johnston SL: Expression of programmed death-1 ligand (PD-L) 1, PDL2, B7-H3, and inducible costimulator ligand on human respiratory tract epithelial cells and regulation by respiratory syncytial virus and type 1 and 2 cytokines. J Infect Dis 2006;193:404-412.

25 Tsutsumi H, Takeuchi R, Ohsaki M, Seki K, Chiba S: Respiratory syncytial virus infection of human respiratory epithelial cells enhances inducible nitric oxide synthase gene expression. J Leukoc Biol 1999;66:99-104.

26 Groskreutz DJ, Monick MM, Powers LS, Yarovinsky TO, Look DC, Hunninghake GW: Respiratory syncytial virus induces TLR3 protein and protein kinase $\mathrm{R}$, leading to increased double-stranded RNA responsiveness in airway epithelial cells. J Immunol 2006;176:1733-1740.
27 Fujisawa T, Kato Y, Atsuta J, Terada A, Iguchi K, Kamiya H, Yamada H, Nakajima T, Miyamasu M, Hirai K: Chemokine production by the BEAS-2B human bronchial epithelial cells: differential regulation of eotaxin, IL-8, and RANTES by TH2- and TH1-derived cytokines. J Allergy Clin Immunol 2000;105: 126-133.

28 Kato A, Homma T, Batchelor J, Hashimoto N, Imai S, Wakiguchi H, Saito H, Matsumoto K: Interferon-alpha/beta receptor-mediated selective induction of a gene cluster by CpG oligodeoxynucleotide. BMC Immunol 2003;4:8.

29 Reed LJ, Muench H: A simple method of estimating fifty percent endpoints. Am J Hyg 1938;27:493-497.

30 Kado G: Relative sensitivity of three cell substrates to the Sabin poliovirus strains. Dev Biol Stand 1976;37:261-264.

>31 Gower TL, Pastey MK, Peeples ME, Collins PL, McCurdy LH, Hart TK, Guth A, Johnson TR, Graham BS: RhoA signaling is required for respiratory syncytial virus-induced syncytium formation and filamentous virion morphology. J Virol 2005;79:5326-5336.

>32 Garofalo R, Sabry M, Jamaluddin M, Yu RK, Casola A, Ogra PL, Brasier AR: Transcriptional activation of the interleukin- 8 gene by respiratory syncytial virus infection in alveolar epithelial cells: nuclear translocation of the RelA transcription factor as a mechanism producing airway mucosal inflammation. J Virol 1996;70:8773-8781.

33 Olszewska-Pazdrak B, Casola A, Saito T, Alam R, Crowe SE, Mei F, Ogra PL, Garofalo RP: Cell-specific expression of RANTES, MCP-1, and MIP-1alpha by lower airway epithelial cells and eosinophils infected with respiratory syncytial virus. J Virol 1998;72: 4756-4764.

34 Amanatidou V, Sourvinos G, Apostolakis S, Neonaki P, Tsilimigaki A, Krambovitis E, Spandidos DA: RANTES promoter gene polymorphisms and susceptibility to severe respiratory syncytial virus-induced bronchiolitis. Pediatr Infect Dis J 2008;27:38-42.

>35 Tian M, Liu F, Wen GY, Shi SY, Chen RH, Zhao DY: Effect of variation in RANTES promoter on serum RANTES levels and risk of recurrent wheezing after RSV bronchiolitis in children from Han, Southern China. Eur J Pediatr 2009;168:963-967.

36 Charo IF, Myers SJ, Herman A, Franci C, Connolly AJ, Coughlin SR: Molecular cloning and functional expression of two monocyte chemoattractant protein 1 receptors reveals alternative splicing of the carboxylterminal tails. Proc Natl Acad Sci USA 1994; 91:2752-2756.

-37 Schweickart VL, Epp A, Raport CJ, Gray PW: CCR11 is a functional receptor for the monocyte chemoattractant protein family of chemokines. Adv Exp Med Biol 1991;305:47-56. 
-38 Garofalo RP, Patti J, Hintz KA, Hill V, Ogra PL, Welliver RC: Macrophage inflammatory protein-1alpha (not $\mathrm{T}$ helper type 2 cytokines) is associated with severe forms of respiratory syncytial virus bronchiolitis. J Infect Dis 2001;184:393-399.

39 Noah TL, Becker S: Chemokines in nasal secretions of normal adults experimentally infected with respiratory syncytial virus. Clin Immunol 2000;9:434-439.

-40 Gu L, Tseng S, Horner RM, Tam C, Loda M, Rollins BJ: Control of $\mathrm{TH} 2$ polarization by the chemokine monocyte chemoattractant protein-1. Nature 2000;404:407-411.

-41 Alam R, York J, Boyars M, Stafford S, Grant JA, Lee J, Forsythe P, Sim T, Ida N: Increased MCP-1, RANTES, and MIP-1alpha in bronchoalveolar lavage fluid of allergic asthmatic patients. Am J Respir Crit Care Med 1996; 153:1398-1404.
42 Tateno H, Nakamura H, Minematsu N, Amakawa K, Terashima T, Fujishima S, Luster AD, Lilly CM, Yamaguchi K: Eotaxin and monocyte chemoattractant protein-1 in chronic eosinophilic pneumonia. Eur Respir J 2001;17:962-968.

43 Yang D, Chertov O, Bykovskaia SN, Chen Q, Buffo MJ, Shogan J, Anderson M, Schröder JM, Wang JM, Howard OM, Oppenheim JJ: Beta-defensins: linking innate and adaptive immunity through dendritic and $\mathrm{T}$ cell CCR6. Science 1999;286:525-528.

44 Robays LJ, Maes T, Lebecque S, Lira SA, Kuziel WA, Brusselle GG, Joos GF, Vermaelen $\mathrm{KV}$ : Chemokine receptor CCR2 but not CCR 5 or CCR6 mediates the increase in pulmonary dendritic cells during allergic airway inflammation. J Immunol 2007;178: 5305-5311.

45 Culley FJ, Pennycook AM, Tregoning JS, Hussell T, Openshaw PJ: Differential chemokine expression following respiratory virus infection reflects Th1- or Th2-biased immunopathology. J Virol 2006;80:4521-4527.
46 Bont L, Heijnen CJ, Kavelaars A, van Aalderen WM, Brus F, Draaisma JM, Pekelharing-Berghuis $M$, van Diemen-Steenvoorde RA, Kimpen JL: Local interferon-gamma levels during respiratory syncytial virus lower respiratory tract infection are associated with disease severity. J Infect Dis 2001;184: 355-358.

47 van Schaik SM, Obot N, Enhorning G, Hintz K, Gross K, Hancock GE, Stack AM, Welliver $\mathrm{RC}$ : Role of interferon gamma in the pathogenesis of primary respiratory syncytial virus infection in BALB/c mice. J Med Virol 2000;62:257-266

48 Tang YW, Graham BS: T cell source of type 1 cytokines determines illness patterns in respiratory syncytial virus-infected mice. J Clin Invest 1997;99:2183-2191.

$\checkmark 49$ Hassantoufighi A, Oglesbee M, Richter BW, Prince GA, Hemming V, Niewiesk S, Eichelberger MC: Respiratory syncytial virus replication is prolonged by a concomitant allergic response. Clin Exp Immunol 2007;148: 218-229. 